\title{
Progesterone, but Not Progesterone-Independent Activation of Progestin Receptors by a Mating Stimulus, Rapidly Decreases Progestin Receptor Immunoreactivity in Female Rat Brain
}

\author{
A. P. Auger,* L. M. LaRiccia,* C. A. Moffatt, $\dagger$ \\ and J. D. Blaustein* \\ *Neuroscience and Behavior Program, Center for Neuroendocrine Studies, Tobin Hall, \\ University of Massachusetts, Amherst, Massachusetts, 01003; and +Department of Biology, \\ San Francisco State University, San Francisco, California 94132
}

Received September 3, 1999; revised November 3, 1999; accepted December 1, 1999

Recent studies suggest that progestin receptors may be activated in vivo by neurotransmitters in the absence of ligand. More specifically, vaginal-cervical stimulation (VCS) can influence sexual behavior by activating progestin receptors in the absence of progesterone. Another way to test if progestin receptors are influenced by particular stimuli is to examine progestin receptor immunostaining. We report that progestin receptor immunoreactivity is decreased in the forebrain of estradiolprimed ovariectomized (OVX) rats within $1 \mathrm{~h}$ after a subcutaneous injection of progesterone, a time by which rapid down-regulation of progestin receptors does not seem to have occurred. In estradiol-primed OVX rats, VCS also decreased progestin receptor immunoreactivity within $1 \mathrm{~h}$ in the medial preoptic area, but not in any other area examined. To determine if the decrease in immunoreactivity by VCS was due to adrenal secretions or by ligand-independent activation of progestin receptors, we repeated the experiment in estradiol-primed $\mathrm{OVX} /$ adrenalectomized rats. Prior removal of the adrenal glands blocked the rapid decrease in progestin receptor immunoreactivity, even though data from other experiments suggest that progestin receptors are activated by VCS at this time. These studies suggest the possibility that progestin receptors may be affected differentially by progesterone-dependent or by progesterone-independent pathways. This raises the possibility that activation of progestin receptors by these two distinct pathways may lead to different neuronal consequences. ○ 2000 Academic Press

Key Words: progesterone; progestin receptors; hypothalamus; preoptic area; progesterone-independent; ligand-independent; mating stimulation; vaginocervical stimulation.
Estrous behaviors in female rats are dependent upon circulating ovarian steroid hormones (Boling and Blandau, 1939). This suite of behaviors is abolished by the removal of the ovaries and can be reinstated by the injection of estradiol followed 1 to 2 days later by progesterone (Boling and Blandau, 1939; Powers, 1970). Estradiol treatment alone can induce certain aspects of estrous behavior, such as sexual receptivity (e.g. lordosis); however, estradiol followed by progesterone induces the full complement of behaviors that occur during normal estrus, such as ear-wiggling, dart-hopping, and solicitational behavior (Blaustein and Olster, 1989; Erskine, 1989; Tennent et al., 1980; Whalen, 1974).

Ovarian steroid hormones influence behavior and physiology at least in part by binding to intracellular steroid receptors (Blaustein and Olster, 1989; Pfaff et al., 1994), although some of the effects of steroid hormones may also involve their binding to membrane receptors (Debold and Frye, 1994). Upon binding, the steroid receptor complex may undergo a conformational change that then results in binding to a hormone response element located on DNA (Jensen et al., 1968; Tsai and O'Malley, 1994; Walters, 1985). Once the steroid receptor complex is bound to DNA, a variety of physiological changes can arise. For example, second messenger systems (Etgen and Petitti, 1986), neurotransmitter/peptide receptor levels (Johnson et al., 1985, 1988; Schumacher et al., 1993), and neurotransmitter release (Etgen et al., 1992) can be altered in response to estradiol and/or progesterone treatment. 
Another mechanism by which intracellular steroid receptors may be influenced or activated is by the recently discovered ligand-independent pathway (Aronica and Katzenellenbogen 1993; Denner et al., 1990b; Power et al., 1991a, b). We have used the term "activation" to refer to a change in the progestin receptor so that it becomes functional with respect to cellular events. Recent data suggest that the progesterone-independent activation of neural progestin receptors under pharmacological (Mani et al., 1994) and nonpharmacological conditions (Auger et al., 1997) influences female rat estrous behavior. Intracerebral infusion of a dopamine $D_{1}$ receptor agonist increases lordosis in estradiol-primed female rats, and this facilitation can be blocked by prior infusion of either antisense oligonucleotides to progestin receptor mRNA or progestin antagonists (Mani et al., 1994). Furthermore, mating stimuli can also apparently influence sexual receptive behavior through ligand-independent activation of progestin receptors. Repeatedly mating estradiol-primed, ovariectomized/ adrenalectomized (OVX/ADX) female rats with males increases the levels of their sexual receptivity within $2 \mathrm{~h}$, and this increase can be blocked by prior injection of a progestin receptor antagonist, such as RU 486 or ZK 98299 (Auger et al., 1997). Vaginal-cervical stimulation (VCS), a component of mating stimuli, also increases sexual receptivity in estradiol-primed, OVX female rats under some conditions (Komisaruk, 1971). The increase in sexual receptivity following mating stimulation can be blocked by progestin antagonists (Auger et al., 1997). Similarly, VCS increases Fos expression in many areas of rat brain, and prior treatment with progestin antagonists blocks these increases in areas that express high levels of progestin receptors, such as the medial preoptic area and the ventromedial hypothalamus. Thus, increases in sexual receptivity or immediate early gene expression exhibited by estradiol-primed, OVX/ADX female rats in response to mating stimuli can be eliminated by prior administration of progestin antagonists even in the absence of circulating progesterone. These data suggest a pathway by which mating stimuli can influence sexual behavior or gene expression by activating progestin receptors in the absence of circulating progesterone.

Another way to test if progestin receptors are influenced by particular stimuli is to examine the immunostaining of antibodies that appear to be affected at least in part by occupation of receptors with ligand. Previous studies in which antibodies directed at particular regions of steroid receptors were used have demonstrated that ligand binding can influence the ability of antibodies directed at particular epitopes to bind to the receptor (Blaustein, 1993; Blaustein and Turcotte, 1989; Meredith et al., 1994; Zhou et al., 1994). Injection of estradiol rapidly decreases estrogen receptor immunostaining in the rat brain with an antibody directed at the hinge region or the ligand binding domain, but not with an antibody that is directed at the N-terminal region of the receptor (Blaustein, 1993). We have interpreted these results as evidence that estrogen receptors are not rapidly down-regulated by estradiol (i.e., within $20 \mathrm{~min}$ ). Rather, the ability of these antibodies to bind to the estrogen receptor has been altered in some way by the occupation of ligand. In contrast, immunostaining of androgen receptors with an antibody directed at the $\mathrm{N}$-terminal region is rapidly increased in the rat brain following treatment with testosterone (Zhou et al., 1994). Therefore, the use of antibodies directed at different regions of steroid receptors provide a useful tool for investigating structural changes that may occur in particular regions of steroid receptors in response to occupation and perhaps activation by ligands.

In this paper we first demonstrate that progestin receptor immunostaining, using an antibody directed at the hinge region of both the $\mathrm{A}$ and $\mathrm{B}$ progestin receptor isoforms, decreases in the forebrain of OVX estradiol-primed female rats within $1 \mathrm{~h}$ following subcutaneous injection of progesterone. We then determined if activation of progestin receptors by mating stimuli also induces a similar decrease in progestin receptor immunoreactivity in the forebrain of either OVX or OVX/ADX estradiol-primed female rats. Although we found that VCS decreases progestin receptor immunoreactivity within $1 \mathrm{~h}$ in estradiol-primed OVX female rats, VCS did not decrease progestin receptor immunoreactivity in estradiol-primed OVX/ ADX female rats. These data suggest the possibility that progestin receptors may be affected differentially via activation by progesterone or progesterone-independent pathways.

\section{MATERIALS AND METHODS}

\section{Animals}

Female Sprague-Dawley rats (200-250 g) obtained from Charles River Breeding Laboratories, Inc. (Wilmington, MA) were group-housed for 1 week in a 14:10 light:dark cycle. All rats were either OVX or OVX/ADX under methohexital sodium anesthesia (52 
$\mathrm{mg} / \mathrm{kg}$ body weight, Brevital, Eli Lilly and Co., Indianapolis, IN) prior to experimentation.

\section{Experiment 1a}

One week following OVX, rats were injected with 5 $\mu \mathrm{g}$ of estradiol benzoate (dissolved in $0.1 \mathrm{ml}$ sesame oil) followed approximately $48 \mathrm{~h}$ later by either injection of $5 \mathrm{mg}$ of progesterone (dissolved in $0.1 \mathrm{ml}$ sesame oil containing $5 \%$ benzyl alcohol and $15 \%$ benzyl benzoate; $n=3$ ) or oil vehicle control $(n=4)$. The rats were perfused $1 \mathrm{~h}$ after the second injection.

\section{Experiment 1b}

One week following OVX, rats were injected with 5 $\mu \mathrm{g}$ of estradiol benzoate (dissolved in $0.1 \mathrm{ml}$ sesame oil) followed approximately $48 \mathrm{~h}$ later by either injection of $0.5 \mathrm{mg}$ of progesterone (dissolved in $0.1 \mathrm{ml}$ sesame oil containing $5 \%$ benzyl alcohol and $15 \%$ benzyl benzoate; $n=5)$ or oil vehicle control $(n=4)$. The rats were perfused $1 \mathrm{~h}$ after the second injection.

\section{Experiment 2a}

One week following OVX, rats were injected with 2 $\mu \mathrm{g}$ of estradiol benzoate (dissolved in $0.1 \mathrm{ml}$ sesame oil) followed approximately $48 \mathrm{~h}$ later by either VCS $(n=5)$ or control perineal stimulation (con stim, $n=$ 6) applied manually by the experimenter. Manual stimulation was performed as described previously (Tetel et al., 1993, 1994a, b), during the dark phase of the illumination cycle. Stimulation was administered in two 5-min sessions, separated by a 3-min interval, with a 1-cc plastic syringe plunger attached to a force gauge (FDN5, Wagner Instruments, Greenwich, CT). Each 5-min session consisted of $10 \mathrm{~s}$ of stimulation followed alternately by $10 \mathrm{~s}$ of no stimulation. Animals receiving VCS received $300 \mathrm{~g}$ of force on the cervix, while animals in the control group received $300 \mathrm{~g}$ of force applied to the perineum, as was done previously (Auger et al., 1996). The rats were perfused $1 \mathrm{~h}$ after the final stimulation.

\section{Experiment 2b}

One week following OVX/ADX, rats were injected with $2 \mu \mathrm{g}$ of estradiol benzoate (dissolved in $0.1 \mathrm{ml}$ sesame oil) followed approximately $48 \mathrm{~h}$ later by either VCS $(n=6)$ or control perineal stimulation (con stim, $n=4$ ) applied manually by the experimenter, as described above. We also repeated this experiment in a second group of rats (VCS, $n=5$; control stim, $n=4)$.

\section{Perfusion}

Rats were anesthetized with sodium pentobarbital (89 $\mathrm{mg} / \mathrm{kg})$ and chloral hydrate $(425 \mathrm{mg} / \mathrm{kg})$ dissolved in saline. The heart was then exposed, and the left ventricle was injected with 5000 units of sodium heparin dissolved in $1 \mathrm{ml}$ of saline $(0.15 \mathrm{M})$. After incision of the right atrium and the left ventricle, a cannula was inserted into the aorta through the incision in the left ventricle. Seventy-five milliliters of saline preceded the flow of $250 \mathrm{ml}$ of fixative $(2 \%$ acrolein in $0.1 \mathrm{M}$ sodium phosphate buffer, $\mathrm{pH}$ 7.2) through the cannula. Perfusion pressure was maintained for $14 \mathrm{~min}$ at $100 \mathrm{~mm} \mathrm{Hg}$, with a flow rate of 25 $\mathrm{ml} / \mathrm{min}$. After the brains were removed and blocked, they were placed into $0.1 \mathrm{M}$ sodium phosphate buffer (pH 7.2) containing 20\% sucrose overnight at $4^{\circ} \mathrm{C}$. Forty-micrometer sections from the preoptic area to the midbrain region were then cut on a freezing microtome and placed into cryoprotectant (Watson et al., 1986) at $-20^{\circ} \mathrm{C}$ until immunocytochemical detection of progestin receptors began.

\section{Immunocytochemistry}

For each animal, a set of one in four sections was removed from cryoprotectant and rinsed three times for $5 \mathrm{~min}$ each in Tris-buffered saline (TBS, pH 7.6). Sections were then pretreated in 1\% sodium borohydride for $10 \mathrm{~min}$ to remove residual aldehydes. Following pretreatment and three additional 5-min rinses in TBS, sections were placed into $1 \% \mathrm{H}_{2} \mathrm{O}_{2}, 20 \%$ normal goat serum, and $1 \%$ bovine serum albumin for 20 min to reduce nonspecific staining and endogenous peroxidase activity. Sections were then incubated with the H928 antibody, a mouse monoclonal progestin receptor antibody directed against the hinge region of both the $\mathrm{A}$ and $\mathrm{B}$ progestin receptor isoforms $(0.2$ $\mu \mathrm{g} / \mathrm{ml}$; StressGen, Biotechnologies Corp., Lot No. 1.0, Victoria, BC, Canada), diluted in modified TBS $\left(4^{\circ} \mathrm{C}\right)$ containing $0.1 \%$ gelatin, $0.02 \%$ sodium azide, $0.5 \%$ Triton X-100, and 1\% normal goat serum for 3 days at $4^{\circ} \mathrm{C}$. Following three 5 -min rinses with the above modified TBS buffer, the tissue sections were incubated in a secondary antiserum ( $3 \mu \mathrm{g} / \mathrm{ml}$ of biotinylated goat anti-mouse IgG, Vector Laboratories, Burlingame, CA) diluted in the modified TBS for $90 \mathrm{~min}$ at room temperature. Sections were then rinsed twice in modified TBS and once in TBS for 5 min each prior to incubation 
in the DH:biotinylated horseradish peroxidase $\mathrm{H}$ complex (1:100 in TBS; Vectastain Elite Kit; Vector Laboratories) for $90 \mathrm{~min}$. Following three additional 5-min rinses in TBS, sections were treated with $0.05 \%$ diaminobenzidine and $0.05 \% \mathrm{H}_{2} \mathrm{O}_{2}$ in TBS for $5 \mathrm{~min}$. Immediately following diaminobenzidine treatment, sections were rinsed three times for $5 \mathrm{~min}$ each in TBS. The sections were then mounted onto glass slides and allowed to dry, after which they were coverslipped with DePeX mounting medium (BDH Laboratory Supplies, Poole, England). Omission of the H928 antibody from the procedure eliminated all immunostaining.

\section{Computer-Aided Image Analysis}

A Leitz Dialux 20 microscope (Ernst Leitz Wetzler GMBH, Germany) was fitted with a MTI CCD72 camera (DAGE MTI, Michigan City, IN) connected to a Macintosh Quadra 700 (Apple Computer, Cupertino, CA). The public domain NIH Image (developed at the U.S. National Institutes of Health and available on the Internet at http://rsb.info.nih.gov/nih-image/) program was used for image analysis.

Prior to tissue examination, the microscope was adjusted for Kohler illumination using $10 \times 10$ magnification. A microscope slide with a black dot was placed under the microscope and viewed on the monitor. The camera gain and black levels were adjusted so that black was at the maximum gray level of 255 pixel density and a clear portion of the slide was within single pixel digits. This allowed the gray level range of H928 immunoreactivity to be from 1 to 255 pixel density. Once the camera gain and black levels were adjusted, they remained calibrated for all sections to be analyzed through a given area. Average pixel density for each section was determined by averaging the mean pixel density and standard deviation for the area to be analyzed. The density threshold option was then set to a maximum of $4 \mathrm{SD}$ above the mean pixel density and to a minimum of 1 pixel density. A new background mean and standard deviation was then determined with this setting so that foreground immunostaining no longer factored into the average background pixel density. The average background pixel density was determined for all sections to be analyzed in a given area, and then the density threshold option was set to a minimum of $4 \mathrm{SD}$ above the mean average background pixel density for all sections and a maximum of 255 pixel density. This procedure effectively determined the mean pixel density of the background area excluding the contributions of foreground immunoreactivity. One carefully matched section for each area per animal was then analyzed bilaterally using the above procedure with the experimenter blind to treatment groups.

\section{Neuroanatomical Areas Analyzed}

Representative sections of neuroanatomical areas that contain progestin receptors were matched using the rat brain atlas of Paxinos and Watson (1986; Figs. 1A-1C). The areas examined were the medial preoptic nucleus (MPO), arcuate nucleus (Arc), and a rostral and caudal section of the ventromedial nucleus of the hypothalamus (VMH; Fig. 1). In the rostral section, the progestin receptor-immunoreactive cells are not confined to the ventrolateral ventromedial nucleus of the hypothalamus (rVHMVL); rather, the cells range from the Nissl-defined rVMHVL and extend dorsally toward the fornix. Thus, we previously defined this area as the ovarian steroid hormone (i.e., estrogen receptor and progestin receptor)-containing area associated with the rVMHVL that extends dorsally (rVMHVLORA) (Auger et al., 1996). In the caudal section, only the caudal ventrolateral aspect of ventromedial hypothalamus (cVMHVL) was analyzed, as the PR-IR cells are confined to this region.

\section{Statistics}

Bilateral measurements of each area were pooled and analyzed using SigmaStat Statistical Analysis System 1.01 (Jandel Scientific, Corte Madera, CA). Immunocytochemical results were analyzed using a Student $t$ test. Results were considered statistically significant at a probability level of less than 0.05 .

\section{RESULTS}

\section{Experiment 1a}

A high dose of progesterone decreases H928 immunostaining in OVX rats. As expected, following estradiol priming, H928 immunoreactivity was observed in the MPO, VMH, and Arc of female rats (Figs. 1 and 2A). Treatment with $5 \mathrm{mg}$ of progesterone significantly decreased the number of the H928-IR cells in the MPO, rVMHVL-ORA, cVMHVL, and Arc within $1 \mathrm{~h}(P<0.05)$. Thus, the presence of progesterone decreases $\mathrm{H} 928$ immunoreactivity in all regions examined in female rat forebrain within $1 \mathrm{~h}$. This decrease is presumably due to the progesterone-occupied pro- 

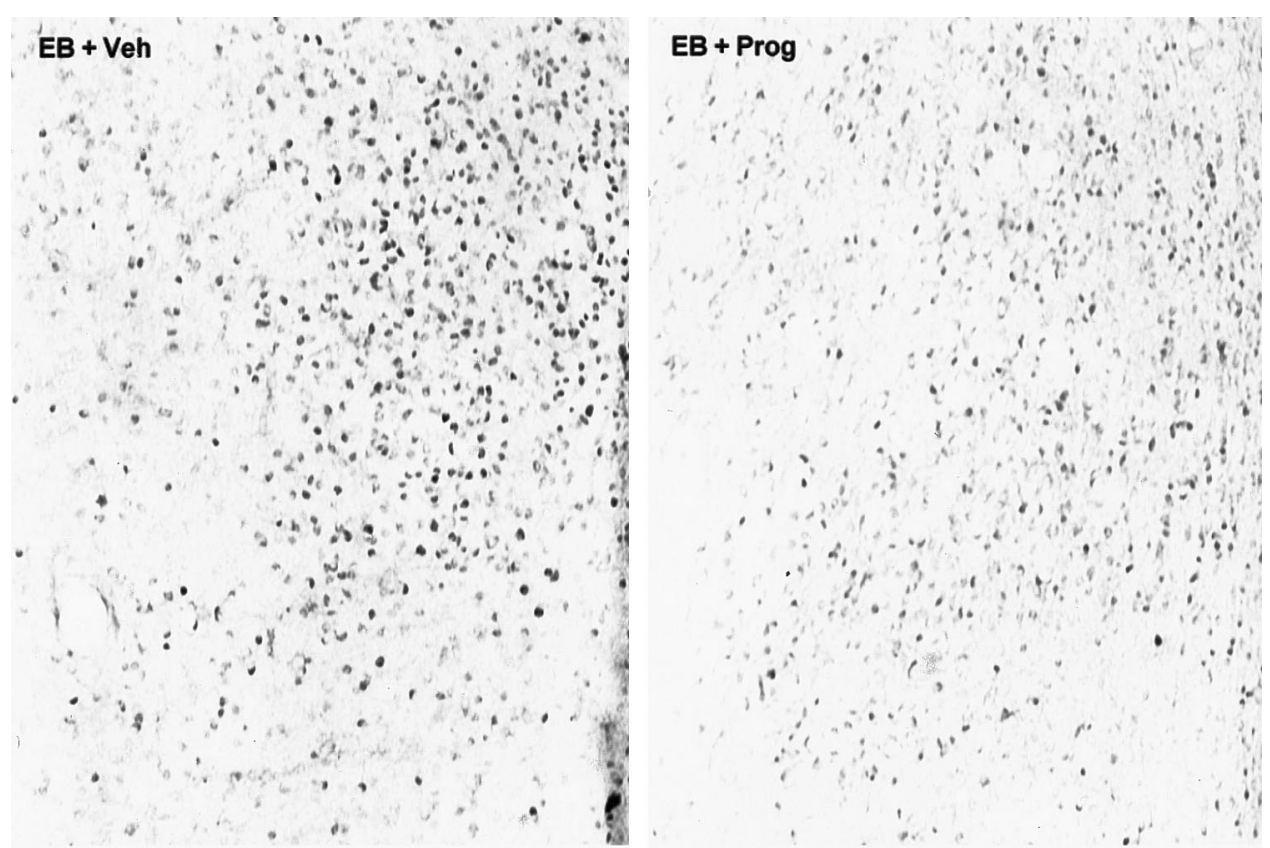

FIG. 1. Photomicrographs of H928-IR cells within the MPO of estradiol-primed rats injected with either 5 mg of progesterone (EB + Prog) or vehicle $(\mathrm{EB}+\mathrm{Veh})$.

gestin receptor having undergone a conformational change that interferes with the subsequent binding of the H928 antibody.

\section{Experiment 1b}

A lower dose of progesterone decreases $\mathrm{H928} \mathrm{immu-}$ nostaining in OVX rats. In estradiol-primed rats, H928 immunoreactivity was again observed in the $\mathrm{MPO}, \mathrm{VMH}$, and Arc (Fig. 2B). Treatment with $0.5 \mathrm{mg}$ of progesterone significantly decreased the number of the H928-IR cells in the MPO, cVMHVL, and Arc within $1 \mathrm{~h}(P<0.05)$. However, $0.5 \mathrm{mg}$ of progesterone did not decrease the number of H928-IR cells within the rVMHVL-ORA.

\section{Experiment 2a}

VCS decreases H928 immunostaining in OVX rats. In estradiol-primed OVX rats, progestin receptor-immunoreactive cells were seen in the $\mathrm{MPO}, \mathrm{VMH}$, and Arc. VCS decreased H928-immunoreactivity in the MPO within $1 \mathrm{~h}$ compared to control perineal stimulation (Figs. 3 and 4A; $P<0.05$ ). In contrast, VCS did not decrease immunostaining in the rVMHVL-ORA, cVMHVL or arcuate nucleus.

\section{Experiment 2b}

VCS does not decrease H928 immunostaining in OVX/ADX rats. In estradiol-primed OVX/ADX rats, progestin receptor immunoreactivity was observed in the MPO, VMH, and Arc. VCS failed to alter the number of H928-immunoreactive cells in any of the regions examined within $1 \mathrm{~h}$ (Figs. 3 and 4B). Therefore, removal of the adrenal glands blocked the effects of VCS on H928-immunostaining in the MPO.

\section{DISCUSSION}

\section{Progesterone Decreases Progestin Receptor Immunostaining}

Consistent with previous findings, the distribution of progestin receptor immunoreactivity was observed in the MPO, VMH, and Arc of estradiol-primed female rats (Auger and Blaustein, 1997; Auger et al., 1996). We found that treatment of estradiol-primed rats with 5 mg of progesterone decreased H928 immunoreactivity in each of the regions of female rat forebrain within $1 \mathrm{~h}$, and $0.5 \mathrm{mg}$ decreased H928 immunoreactivity in all areas except the rVMHVL-ORA.

We suggest that the progesterone-induced decrease in H928 immunoreactivity is due to a conformational 

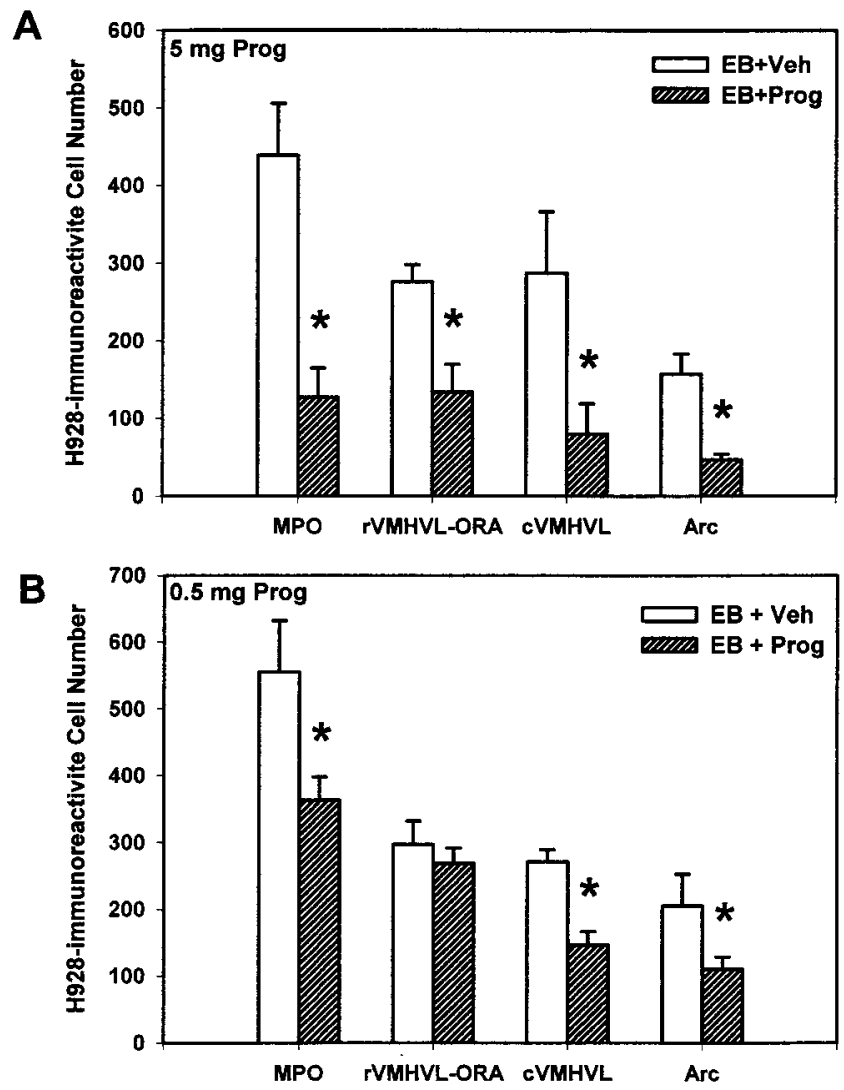

FIG. 2. (A) Mean number ( \pm SEM) of H928-IR cells in estradiolprimed female rats following treatment with either vehicle $(\mathrm{EB}+$ Veh; $n=4$ ) or $5 \mathrm{mg}$ of progesterone (EB + Prog; $n=3)$. (B) Mean number $( \pm$ SEM) of H928-IR cells in estradiol- primed female rats following treatment with either vehicle $(\mathrm{EB}+\mathrm{Veh} ; n=4)$ or $0.5 \mathrm{mg}$ of progesterone (EB + Veh; $n=5)$. MPO, medial preoptic nucleus; rVMHVL-ORA, ovarian steroid hormone (i.e., estrogen and progestin) receptor-containing area associated with the rostral portion of the ventrolateral ventromedial nucleus of the hypothalamus; cVMHVL, caudal ventrolateral aspect of ventromedial hypothalamus; Arc, arcuate nucleus.

change in the progestin receptor caused by binding to progesterone. Although we cannot rule out the possibility that the rapid decrease in H928 immunoreactivity is due to rapid down-regulation of progestin receptors, we believe that this is unlikely because the decrease in immunostaining was not seen in adjacent sections in which a different progestin receptor antibody (DAKO Corp., Carpinteria, CA; data not shown) was used. In agreement with this interpretation, progesterone treatment did not significantly decrease progestin receptor immunostaining in guinea pig brain at $4 \mathrm{~h}$ after injection (Blaustein and Turcotte, 1990). It should be noted that a recent study suggests that estradiol can lead to a rapid catabolism of estrogen receptors within $1 \mathrm{~h}$ in vitro (Alarid et al., 1999). However, the evidence described here suggests that the decreased immunoreactivity is due to progesterone altering the progestin receptor in some way that impedes the binding of the $\mathrm{H} 928$ antibody to the receptor rather than by inducing rapid down-regulation.

\section{VCS Decreases Progestin Receptor Immunostaining in OVX Estradiol-Primed Rats}

As progesterone decreases H928 immunostaining, we wanted to determine if activation of progestin receptors by factors other than progesterone would also decrease H928 immunostaining. We have shown previously that progestin receptors can be activated by mating stimuli in the absence of serum progesterone (Auger et al., 1997). Mating stimuli, including VCS, increase immediate early gene expression (Auger et al., 1996; Pfaus et al., 1993; Tetel et al., 1993) and estrous behavior (Hardy and Debold, 1973; Komisaruk, 1971) within $1 \mathrm{~h}$ in both estradiol-primed OVX and OVX/ADX rats, and VCS-induced Fos expression can be blocked by prior treatment with progestin receptor antagonists (Auger et al., 1997). As VCS seems to activate progestin receptors to influence neuronal response within the $\mathrm{MPO}$ and $\mathrm{VMH}$, we wanted to determine if VCS decreases H928 immunoreactivity at $1 \mathrm{~h}$ within these regions in estradiol-primed OVX rats. Although VCS decreased H928 immunoreactivity within $1 \mathrm{~h}$ in the MPO, it did not affect $\mathrm{H} 928$ immunostaining in the rVMHVL-ORA, cVMHVL, or Arc.

\section{VCS Does Not Decrease Progestin Receptor Immunostaining in OVX/ADX Estradiol-Primed Rats}

It is known that the adrenal glands secrete progesterone in response to mating stimuli (Frye et al., 1996; Smith and Neill, 1976), as well as to a variety of other stimuli (Piva et al., 1973). To determine whether the decrease in $\mathrm{H} 928$ immunoreactivity within the MPO was due to the release of progesterone by the adrenal glands in response to VCS, we repeated the experiment in estradiol-primed OVX/ADX rats. We found that removal of the adrenal glands blocked the decrease in H928 immunoreactivity observed following VCS in adrenal-intact rats despite the fact that progestin receptors are activated in a progesterone-independent manner by mating stimuli at this time point (Auger et al., 1997). 


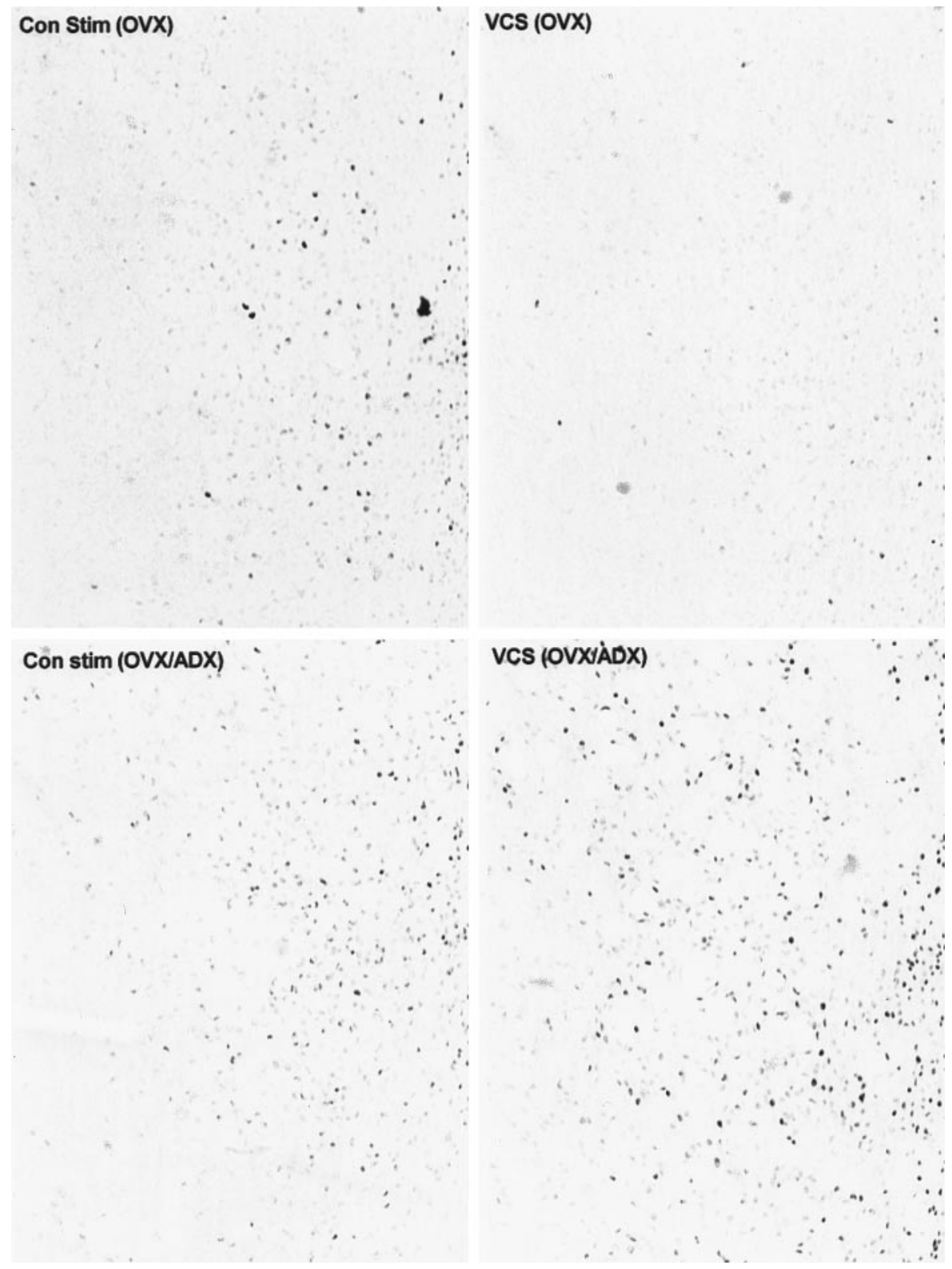

FIG. 3. Photomicrographs of H928-IR cells within the MPO of estradiol-primed OVX rats following VCS or Con Stim (top panels). Bottom panels are photomicrographs of H928-IR cells with the MPO of estradiol-primed OVX/ADX rats following VCS or Con Stim.

\section{Are Progestin Receptors Affected Differentially by Progesterone or by VCS?}

These data suggest two possible mechanisms by which progestin receptors can be activated. When progestin receptors are activated by binding to progesterone, a conformational change in the hinge region may occur so that the receptor is not recognized by the H928 antibody. In contrast, the hinge region of progestin receptors activated in the absence of progester- one may either remain in or assume a form that can still be recognized by the H928 antibody. Therefore, it is possible that progestin receptors undergo a particular conformational change depending on whether they are activated in a progesterone-dependent or progesterone-independent manner. Consistent with this hypothesis, progesterone-activation induces phosphorylation of progestin receptors at $\operatorname{Ser}^{530}$ and $\operatorname{Ser}^{367}$ (Denner et al., 1990a; Poletti and Weigel, 1993), 

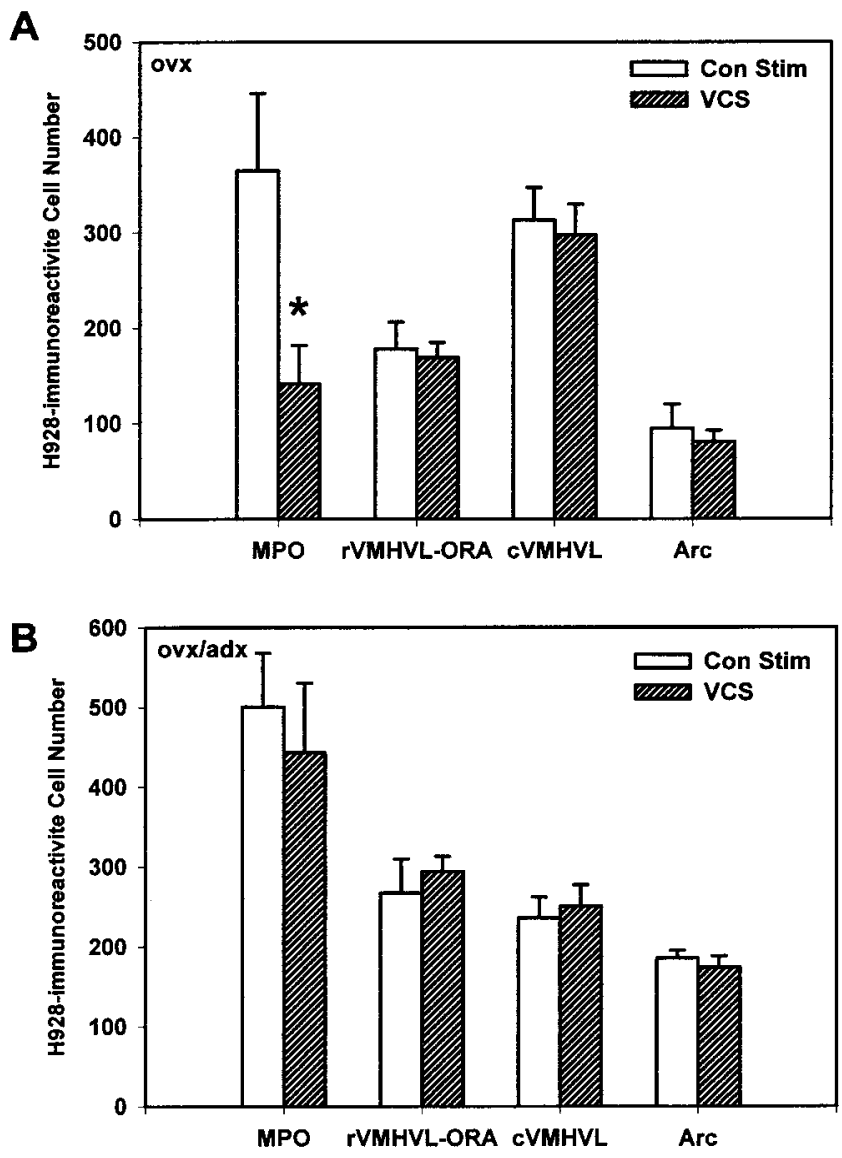

FIG. 4. (A) Mean number ( \pm SEM) of H928-IR cells in estradiolprimed OVX rats $1 \mathrm{~h}$ following VCS $(n=5)$ or Con Stim $(n=6)$. (B) Mean number ( \pm SEM) of H928-IR cells in estradiol-primed OVX/ADX rats $1 \mathrm{~h}$ following VCS $(n=6)$ or Con Stim $(n=4)$.

whereas progesterone-independent activation induces the phosphorylation of sites $\operatorname{Ser}^{211}$ and $\operatorname{Ser}^{260}$ (Bai et al., 1997). This suggests that chicken progestin receptors are differentially phosphorylated in response to progesterone-induced or progesterone-independent activation. In addition, phosphorylation of progestin receptors by these two distinct pathways may differentially affect the hinge region of progestin receptors allowing or hindering the binding of the H928 antibody. It is unlikely that the presence of progesterone may physically block the hinge region from being recognized by H928, because the bound progesterone would not be expected to survive the perfusion and preparation of the brain sections for immunocytochemistry. Nevertheless, we cannot exclude this possibility.

It is not clear why VCS decreases H928 immunoreactivity only within the MPO of estradiol-primed OVX rats, while progesterone treatment decreases H928 im- munostaining in most areas examined. If this decrease is due solely to the release of hormones from the adrenal glands in response to VCS, then we would have expected to see a decrease in H928 immunoreactivity in the other areas examined. However, it is possible that VCS causes a subtle decrease in H928 immunoreactivity in areas other than the MPO, but the sensitivity of our immunocytochemical techniques could be insufficient to detect this magnitude of change in immunostaining in those areas. Alternatively, some neuronal areas may be more sensitive to hormonal stimulation than others. For example, $5 \mathrm{mg}$ of progesterone decreased progestin receptor immunoreactivity in all areas examined; in contrast, $0.5 \mathrm{mg}$ of progesterone did not decrease progestin receptor immunoreactivity in the rVMHVL-ORA but did so in other areas.

\section{Is Neurally Derived Progesterone Involved in VCS-Induced Activation of Progestin Receptors?}

We have interpreted earlier results that progesterone antagonists block dopaminergic facilitation of sexual behavior (Mani et al., 1994), VCS-induced Fos (Auger et al., 1997) and mating-induced potentiation of sexual behavior (Auger et al., 1997) as evidence that some neurotransmitters influence the brain via ligandindependent activation of progestin receptors. An alternative hypothesis is that these neurotransmitters induce the synthesis and/or release of progesterone that has recently been shown to be synthesized de novo in rat brain tissue (Baulieu et al., 1996; Corpechot et al., 1993). However, the present results argue against this alternative hypothesis; if mating stimuli were inducing synthesis and/or release of progesterone synthesized in brain, then we would have expected to observe a similar decrease in H928 immunostaining in OVX/ADX rats. Our data do not support a role for the neurosteroid progesterone in mating-induced activation of progestin receptors.

\section{Involvement of the Adrenal Glands}

These data also support the idea that secretions of the adrenal glands in response to mating stimuli are sufficient to affect progestin receptors in the brain. Indeed, removal of the adrenal glands increases progestin receptor levels in the brain (Etgen, 1985), the anterior pituitary, and the uterus of rats (Evans et al., 1978). The increase in progestin receptors in the rat brain following adrenalectomy may explain why VCS decreases H928 immunoreactivity in the MPO of OVX 
rats but not in OVX/ADX rats. An increase in progestin receptors in rat brain following adrenalectomy might obscure a subtle decrease in H928 immunoreactivity. The adrenal glands are important in influencing the normal timing of estrous behavior in rats, as sham ovariectomy advances and adrenalectomy delays the onset of estrous behavior (Barfield and Lisk, 1974; Nequin and Schwartz, 1971). The adrenal glands also appear to be important in influencing proceptive behavior, as adrenalectomy inhibits proceptive behavior that can be observed following estradiol injection (Tennent et al., 1980). Therefore, in addition to the well-characterized influence of the adrenal glands on the behavior and physiology of rats, the present results suggest that they may also affect the way animals respond to a variety of external stimuli.

\section{Summary}

These data not only contribute information about how rat brain progestin receptors can be influenced by the adrenal glands in response to mating stimuli, but they also suggest that the conformational state of a particular region of the progestin receptor may be influenced differently when activated by progesterone-dependent vs progesterone-independent pathways. If progestin receptors can be activated differentially, then it is possible that progestin receptors may have different physiological effects depending upon whether they are activated by progesterone or by a progesterone-independent mechanism.

\section{ACKNOWLEDGMENTS}

This research was supported by MH 11392 to A.P.A., HD 08181 to C.A.M., and NS 19327 and Senior Scientist Award MH 01312 to J.D.B. from the National Institutes of Health. We gratefully acknowledge Robin Lempicki for expert technical assistance.

\section{REFERENCES}

Alarid, E. T., Bakopoulos, N., and Solodin, N. (1999). Proteasomemediated proteolysis of estrogen receptor: A novel component in autologous down-regulation. Mol. Endocrinol. 13, 1522-1534.

Aronica, S. M., and Katzenellenbogen, B. S. (1993). Stimulation of estrogen receptor-mediated transcription and alteration in the phosphorylation state of the rat uterine estrogen. Mol. Endocrinol. 7, 743-752.

Auger, A. P., and Blaustein, J. D. (1997). Progesterone treatment increases Fos-immunoreactivity within some progestin receptorcontaining neurons in localized regions of female rat forebrain. Brain Res. 746, 164-170.
Auger, A. P., Moffatt, C. A., and Blaustein, J. D. (1996). Reproductively-relevent stimuli induce Fos-immunoreactivity within progestin receptor-containing cells in localized regions of rat forebrain. J. Neuroendocrinol. 8, 831-838.

Auger, A. P., Moffatt, C. A., and Blaustein, J. D. (1997). Progesterone-independent activation of rat brain progestin receptors by reproductive stimuli. Endocrinology 138, 511-514.

Bai, W., Rowan, B. G., Allgood, V. E., O'Malley, B. W., and Weigel, N. L. (1997). Differential phosphorylation of chicken progesterone receptor in hormone-dependent and ligand-independent activation. J. Biol. Chem. 272, 10457-10463.

Barfield, M. A., and Lisk, R. D. (1974). Relative contributions of ovarian and adrenal progesterone to the timing of heat in the 4-day cyclic rat. Endocrinology 94, 571-575.

Baulieu, E. E., Schumacher, M., Koenig, H., Jungtestas, I., and Akwa, Y. (1996). Progesterone as a neurosteroid: Actions within the nervous system. Cell Mol. Neurobiol. 16(2), 143-154.

Blaustein, J. D. (1993). Estrogen receptor immunoreactivity in rat brain: Rapid effects of estrodiol injection. Endocrinology 132, 1218 1224.

Blaustein, J. D., and Olster, D. H. (1989). Gonadal steroid hormone receptors and social behaviors. In (Balthazart, J., Ed.), Advances in Comparative and Environmental Physiology, pp. 31-104. Berlin, Springer-Verlag.

Blaustein, J. D., and Turcotte, J. C. (1989). Estrogen receptor-immunostaining of neuronal cytoplasmic processes as well as cell nuclei in guinea pig brain. Brain Res. 495, 75-82.

Blaustein, J. D., and Turcotte, J. C. (1990). Down-regulation of progestin receptors in guinea pig brain: New findings using an immunocytochemical technique. J. Neurobiol. 21, 675-685.

Boling, J. L., and Blandau, R. J. (1939). The estrogen-progesterone induction of mating responses in the spayed female rat. Endocrinology 25, 359-364.

Corpechot, C., Young, J., Calvel, M., Wehrey, C., Veltz, J. N., Touyer, G., Mouren, M., Prasad, V. V. K., Banner, C., Sjovall, J., Baulieu, E. E., and Robel, P. (1993). Neurosteroids: $3 \alpha$-Hydroxy-5 $\alpha$-pregnan-20-one and its precursors in the brain, plasma, and steroidogenic glands of male and female rats. Endocrinology 133, 1003 1009.

Debold, J. F., and Frye, C. A. (1994). Progesterone and the neural mechanisms of hamster sexual behavior. Psychoneuroendocrinology 19, 563-579.

Denner, L. A., Schrader, W. T., O'Malley, B. W., and Weigel, N. L. (1990a). Hormonal regulation and identification of chicken progesterone receptor phosphorylation sites. J. Biol. Chem. 265, 16548-16555.

Denner, L. A., Weigel, N. L., Maxwell, B. L., Schrader, W. T., and O'Malley, B. W. (1990b). Regulation of progesterone receptormediated transcription by phosphorylation. Science 250, 17401743.

Erskine, M. S. (1989). Solicitation behavior in the estrous female rat: A review. Horm. Behav. 23, 473-502.

Etgen, A. M. (1985). Effects of body weight, adrenal status, and estrogen priming on hypothalamic progestin receptors in male and female rats. J. Neurosci. 5, 2439-2442.

Etgen, A. M., and Petitti, N. (1986). Norepinephrine-stimulated cAMP accumulation in rat hypothalamus slices: Effects of estrous cycle and ovarian steroids. Brain Res. 375, 385-390.

Etgen, A. M., Ungar, S., and Petitti, N. (1992). Estradiol and progesterone modulation of norepinephrine neurotransmission: Implications for the regulation of female reproductive behavior. J. Neuroendocrinol. 4, 255-271. 
Evans, R. W., Sholiton, L. J., and Leavitt, W. W. (1978). Progesterone receptor in the rat anterior pituitary: Effect of estrogen priming and adrenalectomy. Steroids 31, 69-81.

Frye, C. A., McCormick, C. M., Coopersmith, C., and Erskine, M. S. (1996). Effects of paced and non-paced mating stimulation on plasma progesterone, 3 alpha-diol and corticosterone. Psychoneuroendocrinology 21(4), 431-439.

Hardy, D. F., and Debold, J. F. (1973). Effects of repeated testing on sexual behavior of the female rat. J. Comp. Physiol. Psychol. 85, 195-202.

Jensen, E. V., Suzuki, T., Kawashima, T., Stumpf, W. E., Jungblut, P. W., and DeSombre, E. R. (1968). A two-step mechanism for the interaction of estradiol with rat uterus. Proc. Natl. Acad. Sci. USA $59,632-638$.

Johnson, A. E., Nock, B., McEwen, B., and Feder, H. H. (1985). Estradiol modulation of $\alpha_{2}$-noradrenergic receptors in guinea pig brain assessed by tritium-sensitive film autoradiography. Brain Res. 336, 153-157.

Johnson, A. E., Nock, B., McEwen, B. S., and Feder, H. H. (1988). $\alpha_{1}$ and $\alpha_{2}$-noradrenergic receptor binding in guinea pig brain: Sex differences and effects of ovarian steroids. Brain Res. 442, 205-213.

Komisaruk, B. R. (1971). Induction of lordosis in ovariectomized rats by stimulation of the vaginal cervix: Hormonal and hormonal and neural interrelationships. In (Sawyer, C. H., and Gorski, R. A., Eds.), Steroid Hormones and Brain Function, pp. 127-136. Univ. of California Press, Berkley.

Mani, S. K., Allen, J. M. C., Clark, J. H., Blaustein, J. D., and O'Malley, B. W. (1994). Convergent pathways for steroid hormone- and neurotransmitter- induced rat sexual behavior. Science 265, 1246-1249.

Meredith, J. M., Auger, C. J., and Blaustein, J. D. (1994). Downregulation of estrogen receptor immunoreactivity by $17 \beta$-estradiol in the guinea pig forebrain. J. Neuroendocrinol. 6, 639-648.

Nequin, L. G., and Schwartz, N. B. (1971). Adrenal participation in the timing of mating and LH release in the cyclic rat. Endocrinology 88, 325-331.

Paxinos, G., and Watson, C. (1986). The Rat Brain in Stereotaxic Coordinates, 2nd ed. Academic Press, Sydney, Australia.

Pfaff, D. W., Schwartz-Giblin, S., McCarthy, M. M., and Kow, L. M. (1994). Cellular and molecular mechanisms of female reproductive behaviors. In Physiology of Reproduction, 2nd ed., Vols. 1 and 2, pp. 107-220. Raven Press, New York.

Pfaus, J. G., Kleopoulos, S. P., Mobbs, C. V., Gibbs, R. B., and Pfaff, D. W. (1993). Sexual stimulation activates c-fos within estrogenconcentrating regions of the female rat forebrain. Brain Res. 624, 253-267.

Piva, F., Gagliano, P., Motta, M., and Martini, L. (1973). Adrenal progesterone: Factors controlling its secretion. Endocrinology 93, 1178-1184.

Poletti, A., and Weigel, N. L. (1993). Identification of a hormonedependent phosphorylation site adjacent to the DNA-binding domain of the chicken progesterone receptor. Mol. Endocrinol. 7, 241-246.

Power, R. F., Lydon, J. P., Conneely, O. M., and O'Malley, B. W. (1991a). Dopamine activation of an orphan of the steroid receptor superfamily. Science 252, 1546-1548.

Power, R. F., Mani, S. K., Codina, J., Conneely, O. M., and O'Malley, B. W. (1991b). Dopaminergic and ligand-independent activation of steroid hormone receptors. Science 254, 1636-1639.

Powers, J. B. (1970). Hormonal control of sexual receptivity during the estrous cycle of the rat. Physiol. Behav. 5, 831-835.

Schumacher, M., Coirini, H., Johnson, A. E., Flanagan, L. M., Frankfurt, M., Pfaff, D. W., and McEwen, B. S. (1993). The oxytocin receptor-A target for steroid hormones. Regul. Pept. 45, 115-119.

Smith, M. S., and Neill, J. D. (1976). A “critical period" for cervicallystimulated prolactin relase. Endocrinology 98, 324-328.

Tennent, B. J., Smith, E. R., and Davidson, J. M. (1980). The effects of estrogen and progesterone on female rat proceptive behavior Horm. Behav. 14, 65-75.

Tetel, M. J., Celentano, D. C., and Blaustein, J. D. (1994a). Intraneuronal convergence of tactile and hormonal stimuli associated with female reproduction in rats. J. Neuroendocrinol. 6, 211-216.

Tetel, M. J., Getzinger, M. J., and Blaustein, J. D. (1993). Fos expression in the rat brain following vaginal-cervical stimulation by mating and probing. J. Neuroendocrinol. 5, 397-404.

Tetel, M. J., Getzinger, M. J., and Blaustein, J. D. (1994b). Estradiol and progesterone influence the response of ventromedial hypothalamic neurons to tactile stimuli associated with female reproduction. Brain Res. 646, 267-272.

Tsai, M. J., and O'Malley, B. W. (1994). Molecular mechanisms of action of steroid/thyroid receptor superfamily members. Annu. Rev. Biochem. 63, 451-486.

Walters, M. R. (1985). Steroid hormone receptors and the nucleus. Endocr. Rev. 6, 512-543.

Watson, R. E., Wiegand, S. J., Clough, R. W., and Hoffman, G. E. (1986). Use of cryoprotectant to maintain long-term peptide immunoreactivity and tissue morphology. Peptides 7, 155-159.

Whalen, R. E. (1974). Estrogen-progesterone induction of mating in female rats. Horm. Behav. 5, 157-162.

Zhou, L., Blaustein, J. D., and DeVries, G. J. (1994). Distribution of androgen receptor immunoreactivity in vasopressin- and oxytocin-immunoreactive neurons in the male rat brain. Endocrinology 134, 2622-2627. 